\title{
Amylolytic Activity in Germinating Sweetpotato (Ipomoea batatas L.) Roots
}

\author{
Vital Hagenimana and Ronald E. Simard \\ Départemente de Sciences et Technologie des Aliments, Université Laval, Sainte-Foy, Québec \\ G1K 7P4, Canada \\ Louis-P. Vézina ${ }^{1}$ \\ Station de Recherche, Agriculture Canada, 2560 Boulevard Hochelaga, Sainte-Foy, Québec \\ GIV 2J3, Canada
}

\begin{abstract}
Additional index words. phosphorylase, starch hydrolysis, sugars
Abstract. In vitro activity measurements indicate that storage sweetpotato roots contain high amounts of extractable amylolytic enzymes. These storage roots also have a very high starch content, a characteristic indicating that the in vitro measurements estimate potential amylolytic activity rather than actual physiological activity. We are interested in optimizing the use of endogenous amylases when processing sweetpotato roots and have undertaken a study to identify physiological parameters that control in vivo starch breakdown. Sweetpotato roots were allowed to germinate for 35 days in controlled conditions. Using a combination of in vitro activity measurements and immunochemical detection, the spatial distribution and changes in activity levels for the three major amylolytic enzymes in storage sweetpotato roots- $\alpha$ amylase, $\beta$-amylase, and starch phosphorylase-have been followed. After 6 days, $\alpha$-amylase protein increased in the outer starchy parenchymatous tissues surrounding the cambium layers, a result suggesting a de novo synthesis of the enzyme in cambium or laticifers layers. $\beta$-Amylase was abundant throughout the root at all times, and its high levels did not directly affect starch degradation rates. Starch phosphorylase protein level remained constant, while its extractable activity increased. Starch content decreased during sweetpotato seed root germination. However, the amount of starch that disappeared during germination was low compared with the calculated starch hydrolysis potential estimated by amylolytic activity measurements.
\end{abstract}

Despite extensive anatomical, physiological, biochemical, and enzymatic investigations devoted to malting and brewing processes, the precise nature of in situ starch breakdown is not entirely clear (Beck and Ziegler, 1989). There is a good possibility that each starchy plant has its own characteristic machinery for hydrolyzing reserve material (Okamoto and Akazawa, 1979), and so far no unified mechanism has been presented to describe the enzymatic hydrolysis of starch reserves in different kinds of starchy plants.

The breakdown of insoluble granular starch material to soluble maltodextrins in plants is thought to be accomplished by endoamylases ( $\alpha$-amylase, EC 3.2.1.1). These are the only enzymes generally considered able to bind to and attack raw starch, and their slow action is responsible for the physical corrosion of starch granules (Manners, 1985). They also are among the major enzymes synthesized during germination (Bewley and Black, 1985; Jones and Jacobsen, 1991). The physiological role of $\beta$ amylase during starch degradation is not clear. Since $\beta$-amylase can hydrolyze chemically solubilized or boiled starches, it has been assumed that the enzyme hydrolyzes starch in vivo (Simpson and Naylor, 1962). The high levels of $\beta$-amylase in germinating cereal grains and its wide distribution in plants have encouraged this assumption. However, $\beta$-amylase is quite ineffective in attacking raw starch granules (Dunn, 1974), and seeds of rye and barley

Received for publication 9 Apr. 1993. Accepted for publication 19 July 1993 Contribution 479 of Sainte-Foy Research Station. We thank the Sainte-Foy Research Station of Agriculture Canada for the growth chamber. V. Hagenimana was a recipient of a scholarship from the Projet de Coopération Institutionnelle Laval/UNR financed by Canadian International Development Agency. The cost of publishing this paper was defrayed in part by the payment of page charges. Under postal regulations, this paper therefore must be hereby marked advertisement solely to indicate this fact.

'To whom reprint requests should be addressed. mutants (Daussant et al., 1981; Kreis et al., 1987) exhibiting very low levels of this enzyme germinate well. Dure (1960) found that $\alpha$-amylase accounts for nine-tenths of the total amylolytic activity in corn seeds at the peak of amylolytic activity during germination, although $\beta$-amylase is abundant in that cereal grain.

Neither $\beta$-amylase nor starch phosphorylase seem to be essential for starch mobilization in germinating peas and this also seems to be the case in other legumes (Halmer, 1985). Hence, $\beta$-amylase may be considered nonphysiologically significant for germination, at least in soybean seeds (Adams et al., 1981) or alfalfa taproots (Volenec et al., 1991). It has been suggested that the enzyme might be a storage protein (Giese and Hejgaard, 1984) or could play an unknown regulatory role in the starch synthesis pathway (Duffus and Rosie, 1973).

In sweetpotato roots, the main constituents of the dry matter are carbohydrates, specifically starch (Woolfe, 1992). In addition to high starch content, sweetpotato roots have a high content of amylases (mainly $\beta$-amylase) (Li and Kazuko, 1985). The native amylases have important and well-documented influences on sweetpotato root storage and processing (Deobald et al., 1968; Hoover, 1967; Hoover and Harmon, 1967; Walter et al., 1975). The fresh sweetpotato root contains very little $\alpha$-amylase (Ikemiya and Deobald, 1966), which is found concentrated at the periphery of the root (Hagenimana et al., 1992) in a tissue that is removed during peeling. This makes it difficult to control starch hydrolysis (Deobald et al., 1971) during processing, since $\alpha$-amylase seems to be the main enzyme controlling starch degradation (Dunn, 1974).

We are interested in optimizing the use of endogenous amylases when processing sweetpotato roots. The current study has been undertaken to identify parameters controlling amylolytic activity during starch mobilization in germinating roots. In this report, the distribution and activity change levels of $\alpha$-amylase, $\beta$-amylase, and starch phosphorylase in sweetpotato seed root tissues during 
germination are described.

\section{Materials and Methods}

\section{Plant material}

Certified Porto Rico and Beauregard sweetpotato seed roots 2.5 to $5.0 \mathrm{~cm}$ long were purchased from Beamon Brothers (Goldsboro, N.C.). These two varieties were chosen because they have significantly different levels of amylolytic activity per gram fresh weight. They were germinated in $23-\mathrm{cm}$ pots containing moist sterilized vermiculite. Germination was carried out at 28 to $30 \mathrm{C}$ and $95 \%$ to $98 \%$ relative humidity for 35 days in the dark.

\section{Antibody production}

Sweetpotato $\alpha$ - and $\beta$-amylase antibodies were raised as previously described (Hagenimana et al., 1992). Antistarch phosphorylase antiserum was a gift from N. Brisson, Univ. de Montréal, and was prepared as previously described (Brisson et al., 1989).

\section{Amylase assays}

Extraction. Sliced sweetpotato seed roots (150 g) were homogenized in a Waring blender for $1 \mathrm{~min}$ with $300 \mathrm{ml}$ of cold extraction buffer consisting of $50 \mathrm{~mm}$ sodium citrate ( $\mathrm{pH} 6.9), 2 \mathrm{~mm}$ dithiothreitol, and $0.1 \mathrm{~mm}$ EDTA and then filtered through four layers of cheesecloth. This extract was centrifuged for $20 \mathrm{~min}$ at $13,200 \times g$, and the supernatant was used in amylase activity assays.

Total amylase activity. Total amylase activity was assayed as described by Bernfeld (1955) at 40C.

$\alpha$-Amylase assay. $\alpha$-Amylase activity was determined by the method of Hall et al. (1970), with an assay based on the hydrolysis of amylose azure $\left(20 \mathrm{mg} \cdot \mathrm{ml}^{-1}\right)$. The assay mixture was prepared in $20 \mathrm{~mm}$ sodium-phosphate buffer ( $\mathrm{pH}$ 6.0) containing $2 \mathrm{~mm} \mathrm{CaCl}_{2}$ and $5 \mathrm{~mm} \beta$-mercaptoethanol. Assays were conducted at $40 \mathrm{C}$ for $10 \mathrm{~min}$ and the reaction was stopped with $18 \%$ acetic acid (v/v). One unit (U) of activity was defined as the amount of enzyme liberating colored soluble material from amylose azure corresponding to 2.5 absorbance units/min at $595 \mathrm{~nm}$ under described assay conditions.

$\beta$-Amylase assay. $\beta$-Amylase activity was assayed as described by McCleary and Codd (1989). Aliquots of $0.2 \mathrm{ml}$ of the extract (or dilution in $100 \mathrm{~mm}$ sodium malate buffer, $\mathrm{pH}$ 5.5) containing disodium EDTA $(1 \mathrm{~mm})$, bovine serum albumin $\left(1 \mathrm{mg} \cdot \mathrm{ml}^{-1}\right)$, and $\mathrm{NaN}_{3}(3 \mathrm{~mm})$ were incubated with $0.2 \mathrm{ml}$ of substrate mixture containing $5 \mathrm{~mm}$ p-nitrophenyl-maltopentaoside and $20 \mathrm{U} \alpha$ glucosidase in distilled water at $40 \mathrm{C}$ for $10 \mathrm{~min}$. The reaction was terminated by adding $1 \%(\mathrm{w} / \mathrm{v})$ Trizma base $(3.0 \mathrm{ml})$ and the absorbance was measured at $410 \mathrm{~nm}$. One unit of enzyme activity was defined as the amount of enzyme releasing $1 \mu \mathrm{mol}$ of $\mathrm{p}$ nitrophenol/min under described assay conditions.

Starch phosphorylase. Starch phosphorylase activity (synthetic) was measured as described by Chang and Su (1986), with soluble starch as primer. The reaction mixture contained $0.05 \mathrm{ml}$ of $20 \mathrm{~mm}$ glucose-1-phosphate (G-6875; Sigma, St. Louis), $0.15 \mathrm{ml}$ of $0.3 \%$ (w/v) soluble starch, and $0.2 \mathrm{ml}$ of sweetpotato extract, for a total volume of $0.5 \mathrm{ml}$. The incubation was performed at $40 \mathrm{C}$ for $5 \mathrm{~min}$ in $40 \mathrm{~mm}$ mes- $\mathrm{NaOH}$ buffer ( $\mathrm{pH}$ 5.9), and the reaction was stopped by adding $0.5 \mathrm{ml}$ of $5 \%$ trichloroacetic acid. A $0.5-\mathrm{ml}$ sample of this mixture was withdrawn, clarified by centrifugation, and used for determining inorganic $\mathrm{P}$ by the method of Fiske and Subbarow (1925).

\section{Tissue immunoblotting}

Nitrocellulose sheets (Bio-Rad, Mississauga, Canada) were first soaked in a small volume of phosphate-buffered saline (PBS) $(\mathrm{pH} 7.4)$ and air-dried. Cross-sections were made from roots and freshly cut sections were blotted onto the nitrocellulose paper for $20 \mathrm{~min}$ at 4C. A transverse section of sweetpotato root is shown in Fig. 1. Nitrocellulose tissue-prints were washed three times in 75 $\mathrm{ml}$ of a solution containing $5 \%$ skim milk powder (Carnation; Nestlé, Don Mills, Canada), 0.01\% Antifoam A (A-5758, Sigma) and $0.001 \%$ merthiolate (T-5125; Sigma) in PBS (pH 7.4) to block protein-binding sites. Blots were incubated for $1 \mathrm{~h}$ at $37 \mathrm{C}$ with 100 $\mathrm{ml}$ (or dilution) of antiserum (anti- $\beta$-amylase, anti- $\alpha$-amylase, or antistarch phosphorylase). Blots were also incubated in blotting solution, with nonimmune serum as blanks. Each blot was washed three times with $75 \mathrm{ml}$ of PBS and again three times with $75 \mathrm{ml}$ of blotting solution. Blots were incubated with $75 \mathrm{ml}$ of peroxidaseconjugated swine anti-rabbit (IgG) solution (Dimension Laboratories, Mississauga, Canada) for $4 \mathrm{~h}$ at room temperature and washed

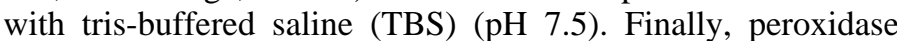
activity was revealed by incubation in $10 \mathrm{ml}$ of $0.6 \%(\mathrm{w} / \mathrm{v})$ of 4chloro-1-naphthol in methanol and $50 \mathrm{ml}$ of $0.08 \%$ (v/v) $\mathrm{H}_{2} \mathrm{O}_{2}$ in TBS at room temperature. The reaction was stopped after $30 \mathrm{sec}$ by washing the blots with $200 \mathrm{ml}$ distilled water.

\section{Chemical analyses}

Moisture. Whole roots were washed and cut into small cubes. Moisture content was determined by drying triplicate 10 -g samples at $60 \mathrm{C}$ for $72 \mathrm{~h}$ in a forced-air oven.

Sugars. Four-gram samples of fresh cubed tissue were homogenized with $20 \mathrm{ml}$ of $80 \%$ ethanol using a homogenizer (Polytron; Brinkman, Rexdale, Ont., Canada) at high speed for $1 \mathrm{~min}$. The homogenizer head was washed with another $20 \mathrm{ml}$ of $80 \%$ ethanol, which was added to the slurry. The mixture was filtered through

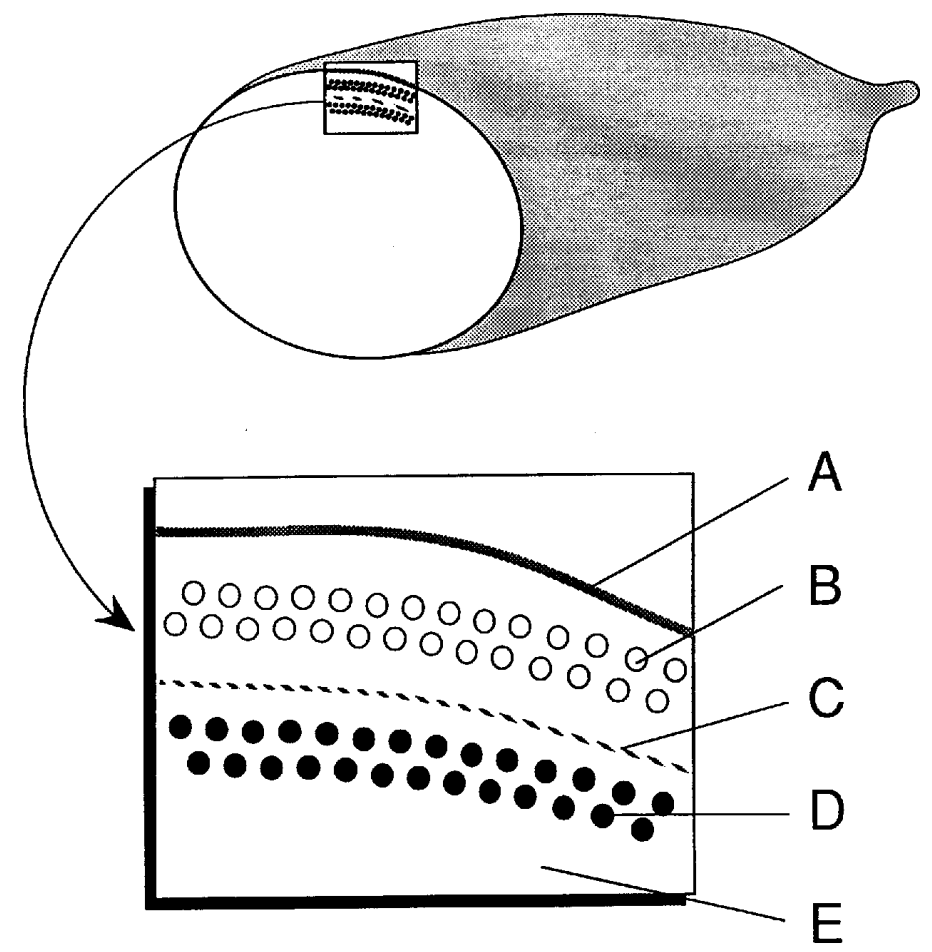

Fig. 1. Diagram of a transverse section of sweetpotato root with relative locations of tissues and cell types pertinent to the present study. (A) Periderm; (B) laticifer (phloem); (C) cambium; (D) xylem element; (E) parenchyma (based on Schadel and Walter, 1981). 


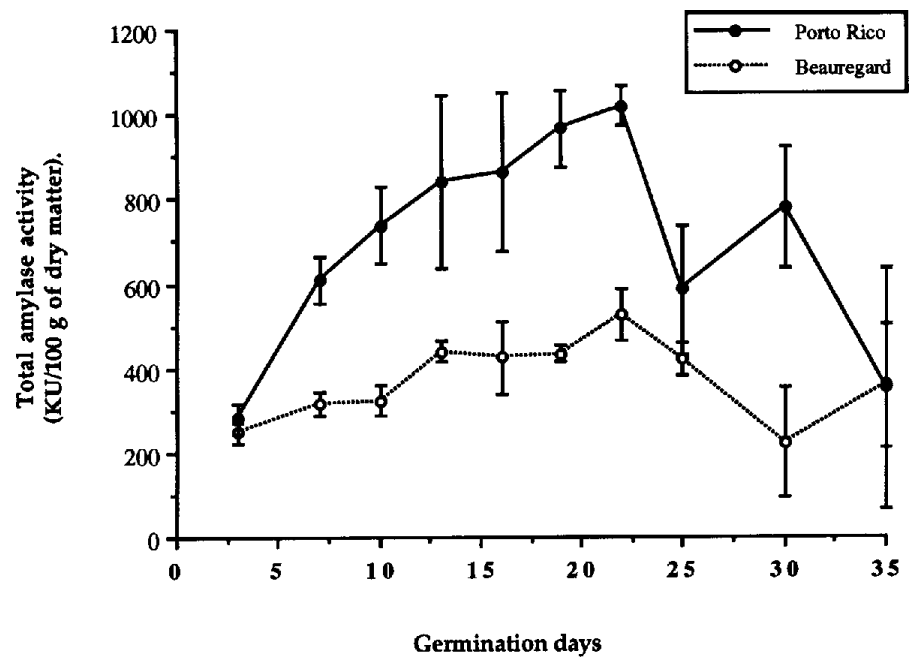

Fig. 2. Total amylase activity during seed root germination in two sweetpotato varieties. Vertical lines represent SDS of the data. Data represent three replications.
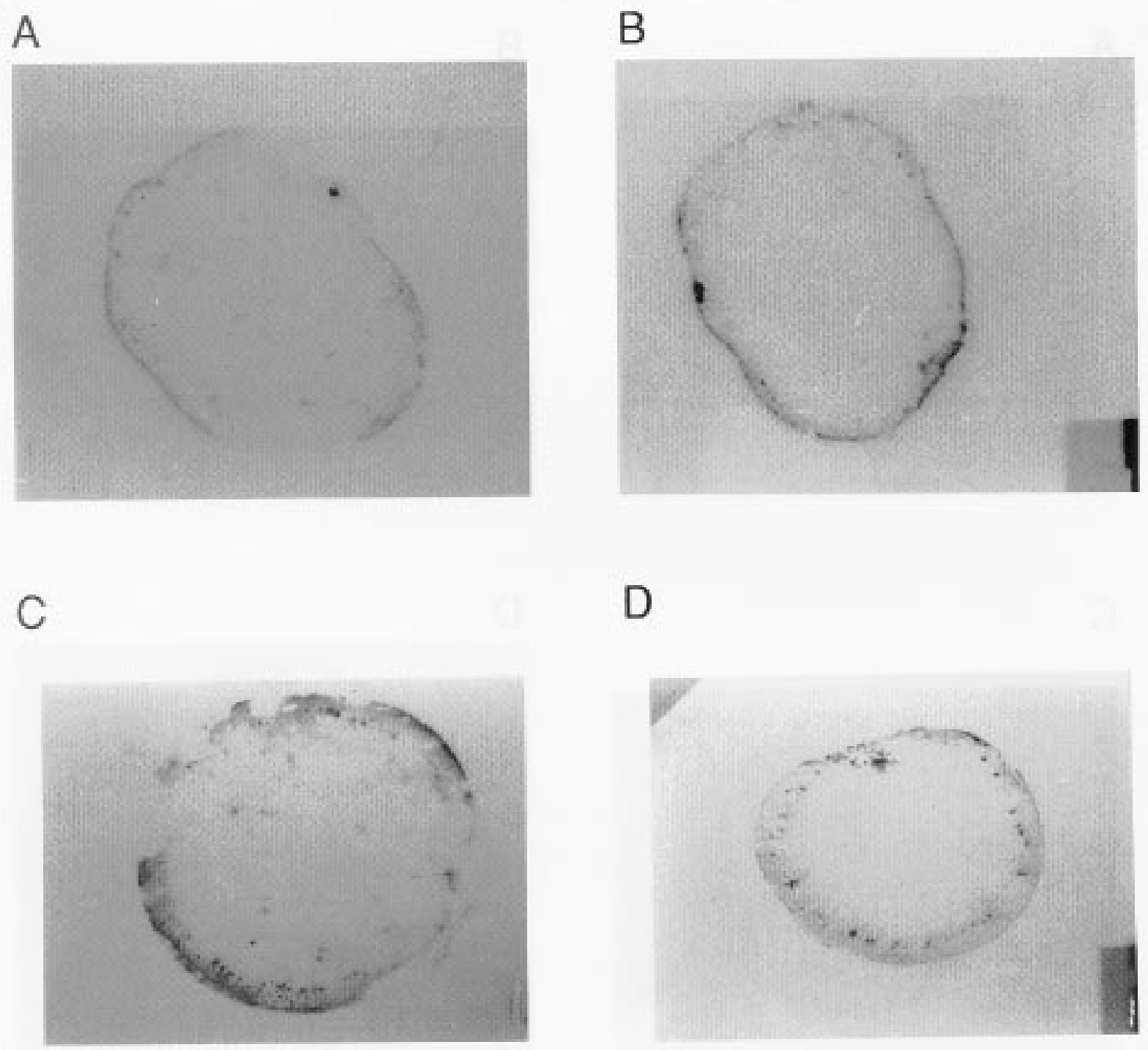

filter paper (Whatman no. 4). The insoluble residue retained on the filter paper was again washed with $20 \mathrm{ml}$ of $80 \%$ ethanol. The filtrate was adjusted to $60 \mathrm{ml}$ and used for determining alcohol soluble sugars by the method of Blakeney and Mutton (1980).

Alcohol insoluble substances (AISs). The insoluble residue retained on the filter paper was dried for $48 \mathrm{~h}$ at $70 \mathrm{C}$, and AISs were calculated based on dry tissue weight.

Starch. From AISs, $30 \mathrm{mg}$ was weighed into a test tube, $10 \mathrm{ml}$ distilled water was added, and the samples were heated to $100 \mathrm{C}$ for $90 \mathrm{~min}$ in a water bath. A standard of soluble starch (S-2630; Sigma) was also run. After cooling, $5 \mathrm{ml}$ of $0.01 \mathrm{M}$ sodium acetate ( $\mathrm{pH} 4.5$ ) containing $10 \mathrm{U} / \mathrm{ml}$ of amyloglucosidase (A-7255; Sigma) was added to each sample. The samples were incubated at $55 \mathrm{C}$ for $30 \mathrm{~min}$, and $75 \mathrm{ml}$ was withdrawn for determining glucose equivalent content, as described by Blakeney and Mutton (1980).

\section{Results}

\section{Distribution and variation in levels of hydrolytic enzymes}

Total amylase activity. Total amylase activity (Fig. 2) increased 


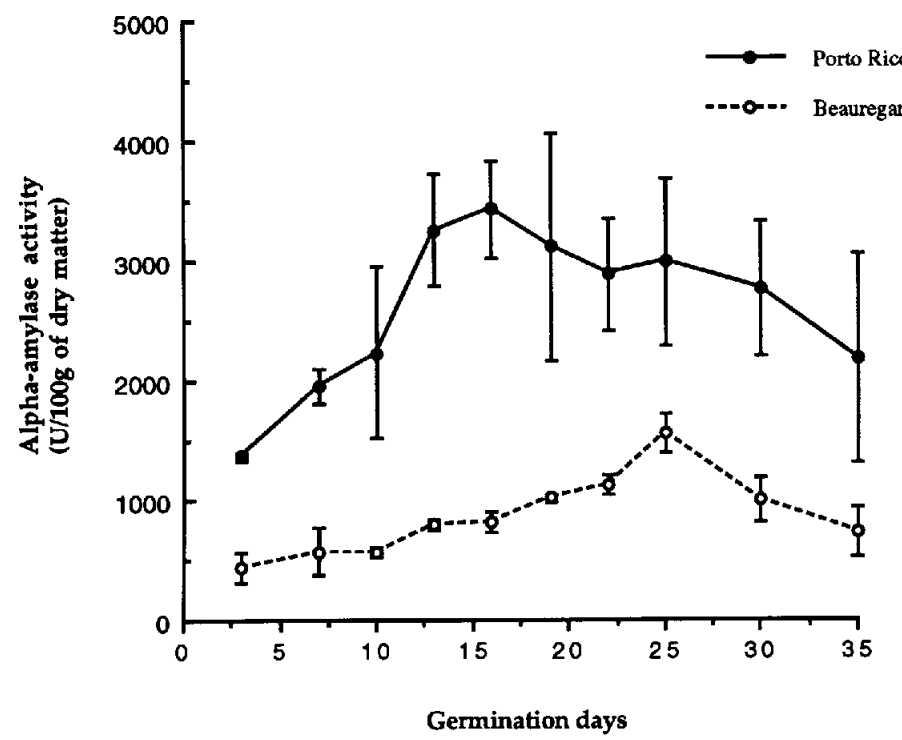

Fig. 4. Evolution of $\alpha$-amylase activity in germinating seed roots of two sweetpotato varieties. Vertical lines represent SDS of the data. Data represent three replications. slowly but continuously during germination and reached a maximum between days 13 and 22 for Porto Rico and around day 22 for Beauregard. Total amylase activity (Fig. 2) was four times greater at day 22 of germination for Porto Rico and two times greater for Beauregard than at the beginning.

$\alpha$-Amylase. At the beginning of germination (day 3 ), tissue immunoblotting (Fig. 3A) showed that $\alpha$-amylase was localized in the outer tissues of the root. Figure $3 \mathrm{~B}-\mathrm{D}$ shows that the enzyme slowly spread from the outer tissue toward the inner tissues at days 9 and 15 . However, this spreading did not cover the entire root even after 35 days of germination. The $\alpha$-amylase protein covered about two-fifths of the root and did not progress deeper within the root, even after 50 days of germination (result not shown). $\alpha$-Amylase activity in Porto Rico increased slowly but continuously in the root up to day 13 and then did not vary significantly (Fig. 4). In Beauregard, $\alpha$-amylase activity was lower than in Porto Rico at the start of germination, but its change in level during germination was similar to that of Porto Rico. It reached a maximum around day 25, although the variation had a lower amplitude.

$\beta$-Amylase. Tissue immunoblots with anti- $\beta$-amylase show that this enzyme is abundant and distributed in all sweetpotato root

B
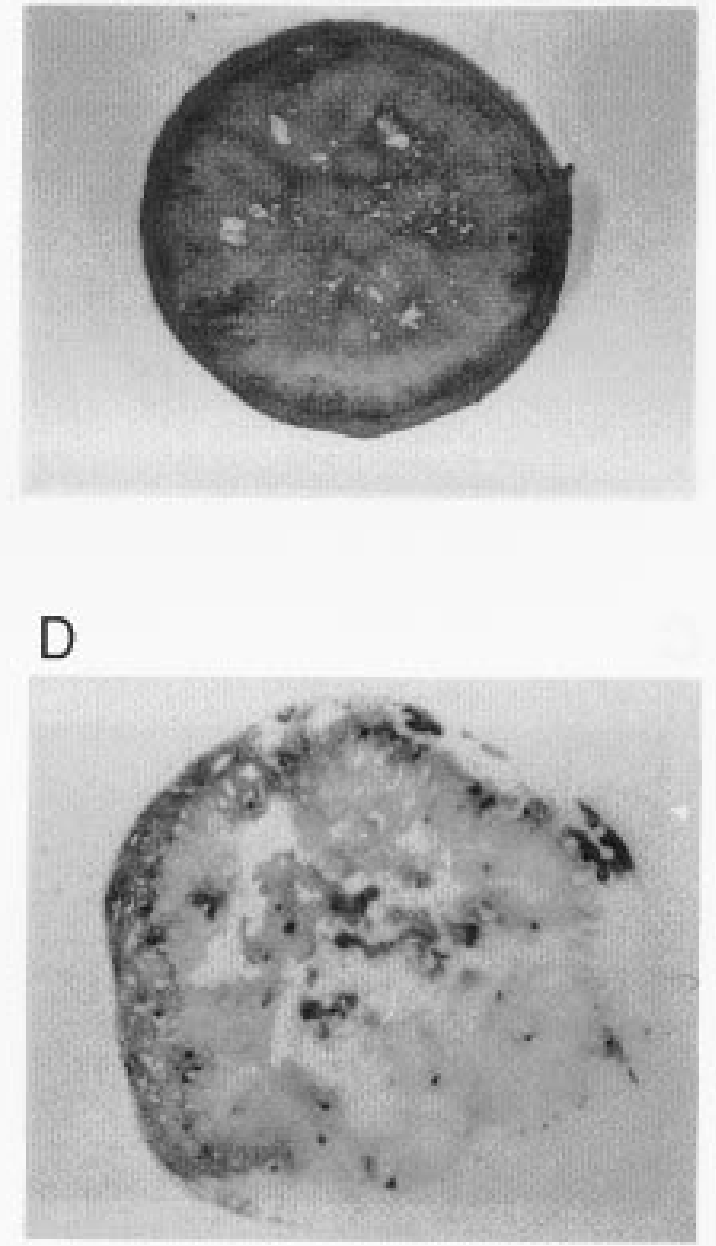

Fig. 5. Tissue print immunoblots of $\beta$-amylase protein in germinating Beauregard sweetpotato root. Freehand cross-section was made after 0 days (A), 7 days (B), 16 days $(\mathbf{C})$, and 34 days $(\mathbf{D})$ of germination. 


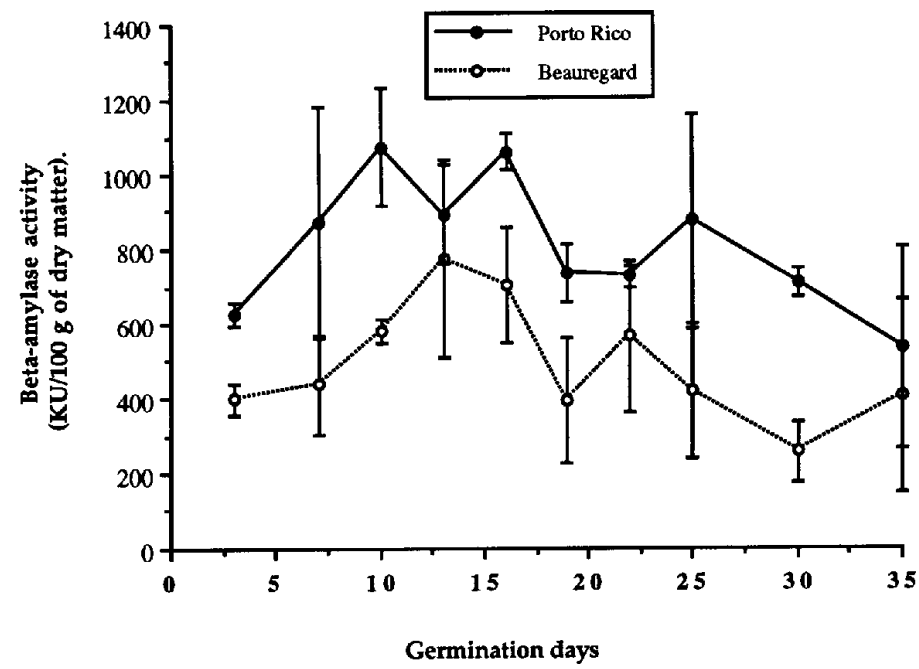

Fig. 6. Evolution of $\beta$-amylase activity in germinating seed roots of two sweetpotato varieties. Vertical lines represent SDS of the data. Data represent three replications. tissue (Fig. 5 A-D ); it remained so during the 35 days of germination. However, for Porto Rico, $\beta$-amylase activity increased slightly during the first 10 days and, thereafter, began to change erratically. For Beauregard, a similar tendency for activity increase was observed up to day 14 (Fig. 6) and then the variation was also irregular.

Starch phosphorylase. Antibodies raised against potato starch phosphorylase cross-reacted with sweetpotato starch phosphorylase. This result agrees with Ariki and Fukui (1975), who found that sweetpotato starch phosphorylase had a similar molecular structure and similar properties to the white potato enzyme, and with Lin et al. (1991), who studied the homology between the coding sequences of starch phosphorylase from potato (Solanum tuberosum) and sweetpotato. They showed that the two genes are highly homologous and encode for identical proteins. To verify that antibodies raised against potato phosphorylase cross-react with only starch phosphorylase from sweetpotato, we have also run sodium dodecyl sulfate polyacrylamide gels of the total protein fraction from 1-year-stored sweetpotato roots (Regal variety),

A

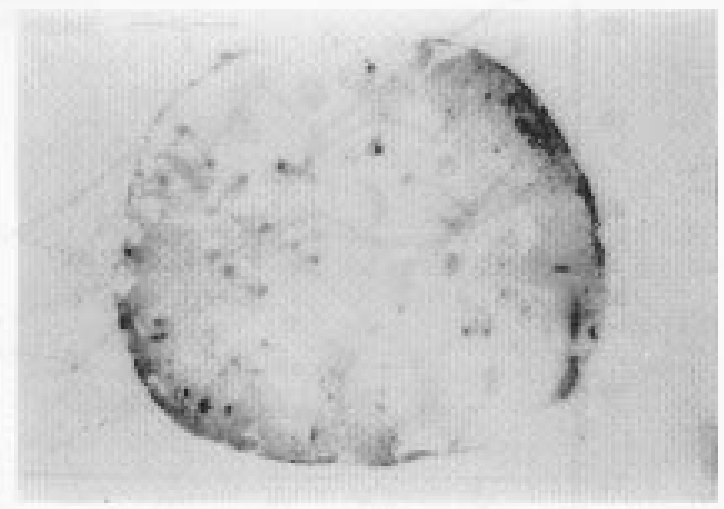

B
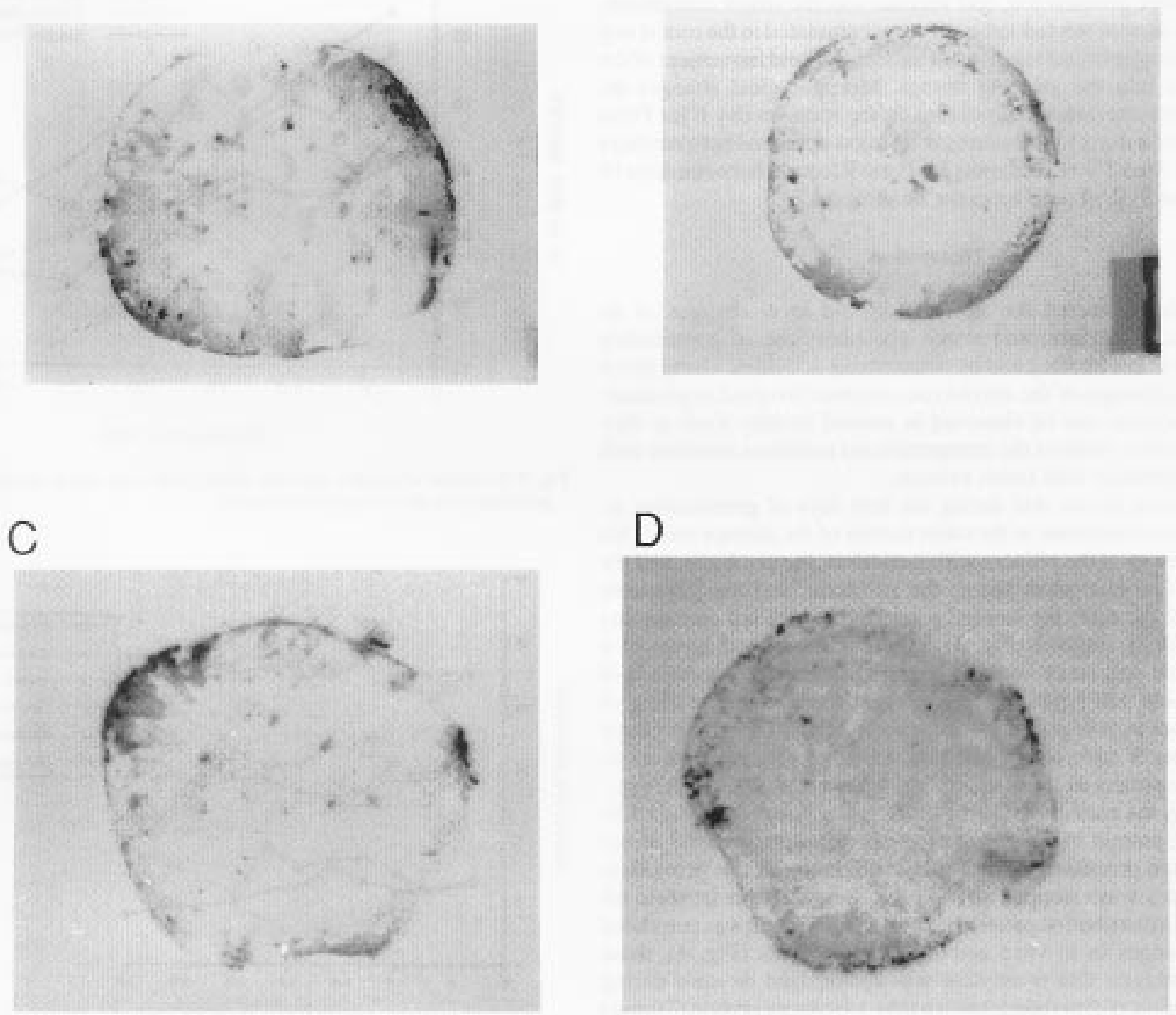

Fig. 7. Tissue print immunoblots of starch phosphorylase protein in germinating Beauregard sweetpotato root. Freehand cross-section was made after 1 day (A), 8 days (B), 15 days $(\mathbf{C})$, and 35 days $(\mathbf{D})$ of germination. 
which contained very high amounts of sporamin $(\approx 70 \%), \beta$ amylase $(\approx 10 \%)$, and $\alpha$-amylase $(\approx 2 \%)$. Proteins were electrotransferred onto nitrocellulose membrane and incubated with the antistarch phosphorylase serum used in our current study. Western blots showed that the antistarch phosphorylase serum does not cross react with $\beta$-amylase, sporamin, or $\alpha$-amylase (data not shown).

With tissue immunoblots, we did not observe quantitative modifications of starch phosphorylase around anomalous cambium or the vascular cambium during germination (Fig. 7 A-D). However, the measured activity for Porto Rico indicated an increase for the first 10 days and then a stabilization to a constant level (Fig. 8); for Beauregard, the activity increased until day 17 and then remained constant. It is interesting to note that starch phosphorylase activity was higher in Porto Rico than in Beauregard at the beginning of germination, but was similar by day 13 and remained so until day 35 of germination.

\section{Chemical and morphological changes}

For both varieties, levels of AISs and starch decreased up to day 35 of germination (Fig. 9). At day 35, starch had decreased by $45 \%$ for Beauregard and by $52 \%$ for Porto Rico. The calculated rate of starch disappearance was $0.4 \mathrm{~g}$ starch per $100 \mathrm{~g}$ dry weight per day for Beauregard and of $0.7 \mathrm{~g}$ starch per $100 \mathrm{~g}$ dry weight per day for Porto Rico. Total sugars level stayed nearly constant (Fig. 10) during root germination, and sucrose was the major constituent. Neither sucrose nor reducing sugars accumulated in the root at any time during germination, a result indicating rapid movement of the products into the growing tissues. Morphological changes included the appearance of radicles on the roots on day 6 for Porto Rico and on day 11 for Beauregard. Shoots appeared between days 10 and 13 in $93 \%$ of seed roots for Porto Rico and between days 16 and 21 in $91 \%$ of seed roots for Beauregard.

\section{Discussion}

We have studied the distribution and level changes of $\alpha$ amylase, $\beta$-amylase, and starch phosphorylase in germinating roots by tissue blotting and by determining activities. Using tissue blotting, changes of the amylolytic enzymes involved in germination processes can be observed in normal healthy roots as they occur in vivo, without the interpretational problems involved with results obtained with tissue extracts.

We have shown that during the first days of germination, $\alpha$ amylase accumulates in the outer tissues of the storage root. This area consists of the phloem with lacticifers, the cambium, and the xylem. The outermost tissue, the periderm, and the large core tissue of the root, the storage parenchyma, did not contain any detectable $\alpha$-amylase (Fig. 3). Figure 1 shows a diagram of a transverse section of sweetpotato root with relative locations of tissues and cell types that are relevant to the understanding of immunodetection results of the present study. Our results show that, after 9 days of germination, there was an increase in $\alpha$ amylase protein in the outer starchy parenchymatous tissues surrounding the cambium layers. There was a visible increase of $\alpha$ amylase protein in the root during germination. Since all of our blots were processed in the same conditions and the peroxidase reactions always stopped after $30 \mathrm{sec}$, and since this increase (or change in distribution pattern) in $\alpha$-amylase protein was correlated with changes in in vitro activity measurements (Fig. 4), these results suggest that $\alpha$-amylase was synthesized de novo during germination. $\alpha$-Amylase is known to be a secretory protein (Tomura and Koshiba, 1985), synthesized in cereal seeds in the scutellum or

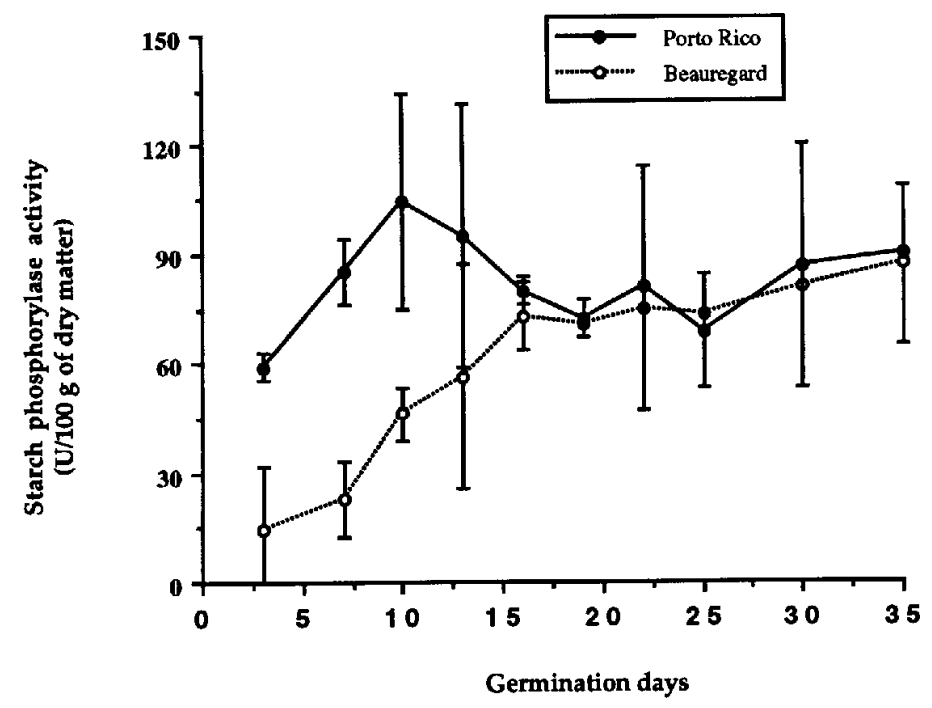

Fig. 8. Starch phosphorylase activity in germinating seed roots of two sweetpotato varieties. Vertical lines represent SDs of the data. Data are for three replications.

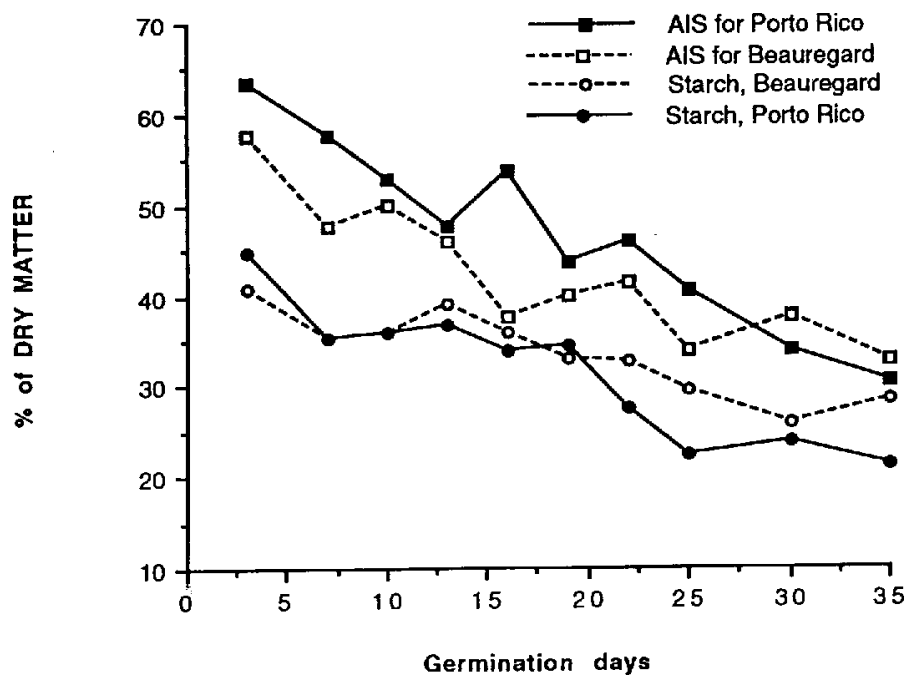

Fig. 9. Evolution of alcohol insoluble solids (AISs) and starch during seed root germination in two sweetpotato varieties.

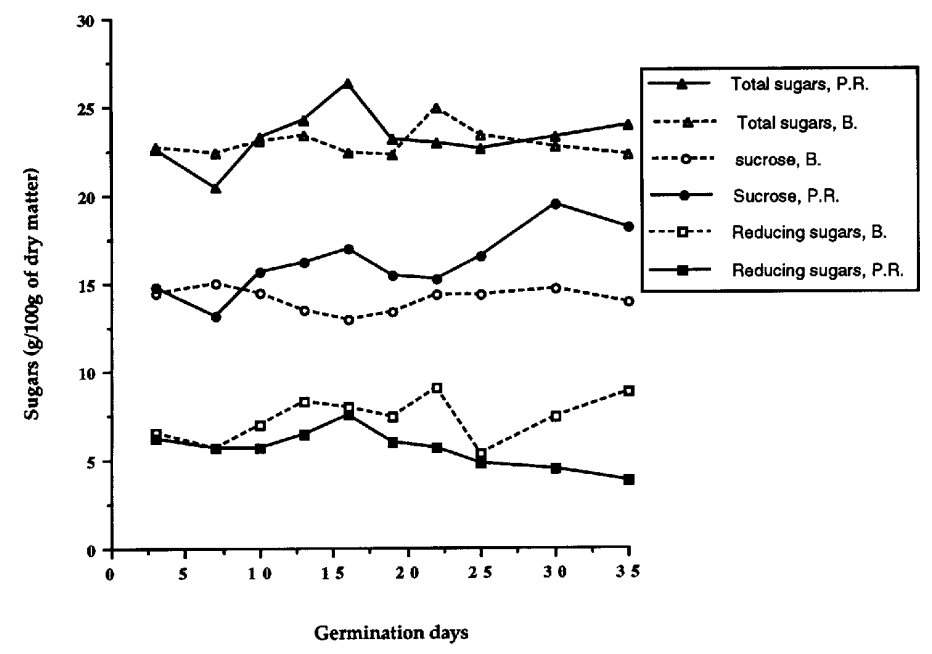

Fig. 10. Total sugars, sucrose, and reducing sugars during seed root germination in two sweetpotato varieties. $\mathrm{B}=$ Beauregard; $\mathrm{PR}=$ Porto Rico. 
in the aleurone layers, that diffuses into the starchy endosperm during germination (McGregory et al., 1984). The results obtained in the current study suggest that $\alpha$-amylase protein is synthesized in cambium or laticifer layers before migrating into the starchy parenchyma tissues of the root during germination.

We also found an increase in total amylolytic activity during germination. Although in both varieties the increase in $\alpha$-amylase activity coincided well with the decrease in starch content (Figs. 4 and 9) and with the increase of total amylases (Figs. 2 and 4), this increase was only moderate in germinating sweetpotato roots. Further, starch measurements for Beauregard have shown that $\approx 14$ $\mathrm{g}$ of starch per $100 \mathrm{~g}$ of dry matter were hydrolyzed during the 35 days of germination. Theoretical calculations based on in vitro activity measurements demonstrate that $\alpha$-amylase could hydrolyze $300 \mathrm{~g}$ of starch during the same period, a result suggesting that basic levels of $\alpha$-amylase alone can account for starch degradation at rates superior to those observed during germination. It is possible that starch degradation is not related to an intensive increase in that enzyme but rather to the change in the distribution of different enzymes or substrates within the subcellular compartments of the germinating root.

Our results from tissue immunoblotting show that $\beta$-amylase was abundant throughout the root at the start of germination and remained so after 35 days of germination (Fig. 5 A-D). These results agree with those reported by Abbott and Matheson (1972), who found that levels of $\beta$-amylase are typically very high in germinating legume and wheat seeds. Starch measurements performed as above for Porto Rico have shown that $\approx 24 \mathrm{~g}$ of starch were hydrolyzed during 35 days of root germination per $100 \mathrm{~g}$ of dry matter. Theoretical calculations based on in vitro activity measurements demonstrate that the $\beta$-amylase present in root could hydrolyze $8800 \mathrm{~g}$ of starch during the same period, a result suggesting that this enzyme would be 360 times in excess in ideal hydrolysis conditions. Moreover, variations in activity levels during germination were not synchronized with measured rates of starch breakdown (Figs. 6 and 9). Therefore, it does not seem likely that levels of $\beta$-amylase would control starch breakdown in situ.

Our tissue blots (Fig. 7 A-D) with antistarch phosphorylase show that the level and distribution of the enzyme remained constant during germination. However, the measured starch phosphorylase activity (Fig. 8) increased with time for Beauregard and Porto Rico. Phosphorylase is probably activated by germination, as reported by Abbott and Matheson (1972). The increase in activity of starch phosphorylase during germination seems to depend on plant species. Starch phosphorylase increase precedes $\alpha$-amylase increase in germinating peas (Juliano and Varner, 1969), it follows a decrease of amylase activity in cotyledons of Voandzeia subterranea (Umezurike and Numfor, 1979), and coincides with an increase in amylases in potato tubers (Abbott and Matheson, 1972) and in sweetpotato (Fig. 8).

In addition to amylases, phosphorylase may be vital for the in vivo degradation of raw sweetpotato starch. It was shown that sweetpotato starch granules cannot be degraded in vitro by adding amylases alone (Hagenimana et al., 1992), and raw potato starch is known to be less susceptible to enzymatic digestion than raw cereal starch (Dreher et al., 1981; Walker and Hope, 1963) because the content of bound $\mathrm{P}$ is higher in roots and tubers than in cereal starch (Greenwood, 1970). Moreover, in Kalanchö̈ daigremontiana, complete starch breakdown is accomplished only if phosphorylase accompanies the action of amylases (Schilling and Dittrich, 1979). However, phosphorylase activity is reported to be reversible in vitro (Salisbury and Ross, 1992; Schneider et al., 1981). It has been reported that the plastid form of the enzyme might be involved in starch synthesis during the amyloplast-filling stage, while the cytosolic form could participate in polyglucan breakdown (Moreno and Tandecarz, 1992; Schneider et al., 1981).

The results obtained in the current study suggest that controlled germination of sweetpotato roots could be of interest for mashing. As an example, a 13-day germination treatment would provide sweetpotato roots with high amylolytic potential $(800 \mathrm{kU}$ for Porto Rico) and high starch level (67\% of initial content). These two physiological parameters are critical for optimizing mashing processes. It has been shown that a mash of barley on its own cannot produce a wort of desirable quality, and malting is necessary to allow the synthesis of amylolytic enzymes, which are natural contributors to the germination, with the minimum expense of reserves (MacLeod, 1979). We think that the $\alpha$-amylase increase during germination (Fig. 3) accompanied by the ubiquity of $\beta$ amylase in the root (Hagenimana et al., 1992) might improve liquefaction and saccharification processes in germinated sweetpotato root mashes.

\section{Conclusion}

Germination induces an increase of amylolytic activity in sweetpotato root, especially that of $\alpha$-amylase in the outer tissues. However, levels of $\beta$-amylase activity are very high and do not seem to control starch degradation. The amount of starch that disappeared during germination was low compared with the calculated starch hydrolysis potential estimated by amylolytic activity measurements. The results obtained in the current study suggest that, besides changes in $\alpha$-amylase, $\beta$-amylase, and starch phosphorylase activity levels, changes in the distribution of these enzymes, or their substrates, may intervene in controlling starch degradation in germinating sweetpotato roots.

\section{Literature cited}

Abbott, I.R. and N.K. Matheson. 1972. Starch depletion in germinating wheat, wrinkled-seeded peas and senescing tobacco leaves. Phytochemistry 11:1261-1272.

Adams, C.A., T.H. Broman, and R.W. Rinne. 1981. Starch metabolism in developing and germinating soy bean seeds is independent of $\beta$-amylase activity. Ann. Bot. 48:433-439.

Ariki, M. and T. Fukui. 1975. $\alpha$-Glucan phosphorylase from sweetpotato: Isolation and properties of the partially degraded enzyme. Biochim. Biophys. Acta 386:301-308.

Beck, E. and P. Ziegler. 1989. Biosynthesis and degradation of starch in higher plants. Annu. Rev. Plant Physiol. Plant Mol. Biol. 40:95-117.

Bernfeld, P. 1955. Amylases, $\alpha$ - and $\beta$-, p. 149. In: S.P. Colowick and N.O. Kaplan (eds.). Methods in enzymology. vol. I. Academic Press, New York.

Bewley, J.D. and M. Black. 1985. Seeds: Physiology of development and germination. Plenum Press, New York.

Blakeney, A.B. and L.L. Mutton. 1980. A simple colorimetric method for the determination of sugars in fruit and vegetables. J. Sci. Food Agr. 31:889-897.

Brisson, N., H. Giroux, M. Zollinger, and A. Camirand. 1989. Maturation and subcellular compartmentation of potato starch phosphorylase. Plant Cell 1:559-566.

Chang, T.C. and J.C. Su. 1986. Starch phosphorylase inhibitor from sweetpotato. Plant Physiol. 80:534-538.

Daussant, J., B. Zbaszyniak, J. Sadowski, and I. Wiatroszak. 1981. Cereal $\beta$-amylase: Immunochemical study on two enzyme-deficient inbred lines of rye. Planta 151:176-179.

Deobald, H.J., V.C. Hasling, and E.A. Catalano. 1971. Variability of increases in alpha-amylase and sugars during storage of Goldrush and Centennial sweetpotatoes. J. Food Sci. 36:413-415.

Deobald, H.J., T.A. McLemore, V.C. Hasling, and E.A. Catalano. 1968. Control of sweetpotato alpha-amylase for producing optimum quality 
precooked dehydrated flakes. Food Technol. 22:627-630

Dreher, M.L., J.C. Schreerens, C.W. Weber, and J.W. Berry. 1981. Nutritional evaluation of Buffalo gourd root starch. Nutr. Rpt. Intl. 23:1-8.

Duffus, C. and R. Rosie. 1973. Starch hydrolyzing enzymes in the developing barley grain. Planta 109:153-160.

Dunn, G. 1974. A model for starch breakdown in higher plants. Phytochemistry 13:1341-1346.

Dure, L.S. 1960. Site of origin and extent of activity of amylases in maize germination. Plant Physiol. 35:925-934.

Fiske, C.H. and Y. Subbarow. 1925. The colorimetric determination of phosphorus. J. Biol. Chem. 66:375-400.

Giese, H. and J. Hejgaard. 1984. Synthesis of salt-soluble proteins in barley. Pulse-labeling study of grain filling in liquid-cultured detached spikes. Planta 161:172-177.

Greenwood, C.T. 1970. Starch and glycogen, p. 471. In: W. Pigman, D. Horton, and A. Herp (eds.). The carbohydrates. Chemistry and biochemistry. Academic Press, New York.

Hagenimana, V., L.P. Vézina, and R.E. Simard. 1992. Distribution of amylases within sweetpotato (Ipomoea batatas L.) root tissues. J. Agr. Food Chem. 40:1777-1783.

Hall, F.F., T.W. Culp, T. Hayakawa, C.R. Ratliff, and N.C. Hightower. 1970. An improved amylase assay using a new starch derivative. Amer. J. Clinical Pathol. 53:627-634.

Halmer, P. 1985. The mobilization of storage carbohydrates in germinated seeds. Physiol. Vég. 23:107-125.

Hoover, M.W. 1967. An enzyme activation process for producing sweetpotato flakes. Food Technol. 21:322-325.

Hoover, M.W. and S.J. Harmon. 1967. Carbohydrate changes in sweetpotato flakes made by the enzyme activation method. Food Technol. 21:1529-1532.

Ikemiya, M. and H.J. Deobald. 1966. New characteristic alpha-amylase from sweetpotatoes. J. Agr. Food Chem. 14:237-240.

Jones, R.L. and J.V.Jacobsen. 1991. Regulation of synthesis and transport of secreted proteins in cereal aleurone. Intl. Rev. Cytol. 126:49-88.

Juliano, B.O. and J.E. Varner. 1969. Enzymic degradation of starch granules in the cotyledons of germinating peas. Plant Physiol. 44:886892.

Kreis, M., M. Williamson, B. Buxton, J. Pywell, J. Hejgaard, and I. Svendsen. 1987. Primary structure and differential expression of $\beta$ amylase in normal and mutant barleys. European J. Biochem. 169:517525.

Li, H. and O. Kazuko. 1985. Major soluble proteins of sweetpotato roots and changes in proteins after cutting, infection, or storage. Agr. Biol. Chem. 49:737-744.

Lin, C.T., K.W. Yeh, P.D. Lee, and J.C. Su. 1991. Primary structure of sweetpotato starch phosphorylase deduced from its cDNA sequence.
Plant Physiol. 95:1250-1253.

MacLeod, A.M. 1979. The physiology of malting, p. 146-224. In: J.R.A. Pollock (ed.). Brewing science. vol. 1. Academic Press, London.

Manners, D.J. 1985. Starch, p. 149-203. In: P.M. Dey and R.A. Dixon (eds.). Biochemistry of storage carbohydrates in green plants. Academic Press, London.

McCleary, B.V. and R. Codd. 1989. Measurement of $\beta$-amylase in cereal flours and commercial enzyme preparations. J. Cereal Sci. 9:17-33.

McGregory, A.W., F.H. McDougall, C. Mayer, and J. Daussant. 1984. Changes in levels of $\alpha$-amylase components in barley tissues during germination and early seedling growth. Plant Physiol. 75:203-206.

Moreno, S. and J. Tandecarz. 1992. Size-activity relationship in phosphorylase of potato tubers after storage. Plant Physiol. Biochem. 30:459465.

Okamoto, K. and T. Akazawa. 1979. Enzymic mechanisms of starch breakdown in germinating rice seeds. VII. Amylase formation in epithelium. Plant Physiol. 63:336-340.

Salisbury, F.B. and C.W. Ross. 1992. Formation of hexose sugars from reserve carbohydrates, p. 267-270. In F.B. Salisbury and C.W. Ross. Plant physiology. 4th ed. Wadsworth Publishing Co., Belmont, Calif.

Schadel, W.E. and W.M. Walter, Jr. 1981. Localization of phenols and polyphenol oxidase in 'Jewel' sweetpotatoes (Ipomoea batatas 'Jewel'). Can. J. Bot. 59:1961-1967.

Schilling, N. and P. Dittrich. 1979. Interaction of hydrolytic and phosphorolytic enzymes of starch metabolism in Kalanchoё daigremontiana. Planta 147:210-215.

Schneider, E.M., J.U. Becker, and D. Volkmann. 1981. Biochemical properties of potato phosphorylase change with its intracellular localization as revealed by immunological methods. Planta 151:124-134.

Simpson, G.M. and J.M. Naylor. 1962. Dormancy studies in seeds of Avena fatua. III. A relationship between maltose, amylases and gibberelin. Can. J. Bot. 40:1659-1673.

Tomura, H. and T. Koshiba. 1985. Biosynthesis of $\alpha$-amylase in Vigna mungo cotyledon. Plant Physiol. 79:939-942.

Umezurike, G.M. and F.A. Numfor. 1979. Changes in content of starch and activities of some enzymes of carbohydrate metabolism in cotyledons of germinating seeds of Voandzeia subterranea. J. Expt. Bot. 30:583-588.

Volenec, J.J., P.J. Boyce, and K.L. Hendershot. 1991. Carbohydrate metabolism in taproots of Medicago sativa L. during winter adaptation and spring regrowth. Plant Physiol. 96:786-793.

Walker, G.J. and P.M. Hope. 1963. The action of some $\alpha$-amylases on starch granules. Biochem. J. 86:452-462.

Walter, W.M., Jr., A.E. Purcell, and A.M. Nelson. 1975. Effects of amylolytic enzymes on "moistness" and carbohydrate changes of baked sweetpotato cultivars. J. Food Sci. 40:793-796.

Woolfe, J.A. 1992. Sweetpotato: An untapped food resource. Cambridge Univ. Press, Cambridge. 